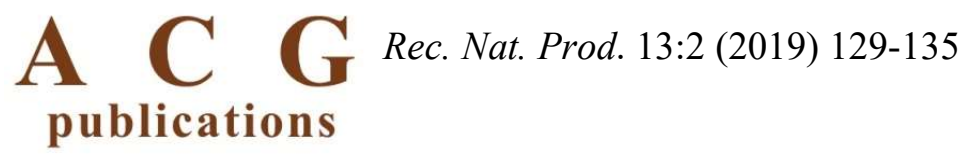

records of natural products

\title{
New Cytotoxic Metabolites from Pathogenic Fungus Cylindrocarpon destructans Associated with Meconopsis grandis
}

\author{
Dilfaraz Khan $\odot^{1,2^{*}}$, Shah Iram Niaz $\odot^{1}$, Kamran Tahir $\odot^{2}$, Hidayat Ullah \\ Khan $\odot^{3}$, Muhammad Haroon $\odot^{4}$, Shahid Ullah Khan $\odot^{5}$, Syed Badshah $\odot^{2}$, \\ Shafiullah Khan $\odot^{2}$, Muafia Jabeen $\odot^{6}$ and Liu Lan $\odot^{1}$ \\ ${ }^{1}$ School of Marine Sciences, Sun Yat-sen University, Guangzhou 510006, China \\ ${ }^{2}$ Institute of Chemical Sciences, Gomal University Dera Ismail Khan 29050, KPK, Pakistan \\ ${ }^{3}$ Department of Chemistry, University of Science and Technology, Bannu 28100 KPK, Pakistan \\ ${ }^{4}$ College of Chemical and Biological Engineering Zhejiang University, Hangzhou 310027, China \\ ${ }^{5}$ National Key laboratory of Crop Genetics and Improvement, Huazhong Agricultute University, \\ Wuhan, China \\ ${ }^{6}$ Department of Pharmacy, COMSATS, Lahore, Pakistan
}

(Received January 13, 2018; Revised March 28, 2018; Accepted April 01, 2018)

\begin{abstract}
Phytochemical investigation on pathogenic fungus Cylindrocarpon destructans isolated form Meconopsisgrandis plant led to the isolation of two new isochromene derivatives namely, 6,8-dimethoxy-3-methyl3,4-dihydrobenzoisochromene-4,9,10-triol (1) and 3,5,6-trihydroxy-4-methylbenzoisochromene-9,11-dione (2) along with four known compounds (3-6). The structures of these compounds were elucidated by 1D and 2D NMR and mass spectroscopic data analysis. The isolated compounds were evaluated for cytotoxic activity. The compounds 1-4 showed good inhibition against the growth of cell lines MCF-7 and PC-3. Compounds 5-6 showed minimum inhibitory effect of cancerous cell lines growth.
\end{abstract}

Keywords: Pathogenic fungus; Cylindrocarpon destructans; Meconopsis grandis; cytotoxic activity (C) 2018 ACG Publications. All rights reserved.

\section{Introduction}

Species of Cylindrocarpon Wollenw. are common and may be isolated as soil inhabitants, saprobes on dead plant material, root colonizers or pathogens, or weak pathogens of various herbaceous and woody plants [1]. Cylindrocarpon destructans (Zinnsm.) [anamorph of Neonectriaradicicola] and C. obtusisporum have been reported to cause the root rots of various hosts [2,3], and a black foot disease of grapevines [4-6]. $C$. destructans $(C$. radicicola) has frequently been reported to cause decay of woody seedlings, especially conifers, and many other hosts as well [2]. Generally this fungus is not severe in its pathogenicity and has been regarded in many cases as the wound infectious fungus or the secondary invader.

\footnotetext{
${ }^{*}$ Corresponding author:E-Mail: dilfarazkhan@gu.edu.pk
} 
Cylindrocarpon species have been rarely associated with human disease. They are known to cause post traumatic keratitis [7, 8] and, have been implicated in mycetoma following injury [9, 10], athlete's foot [11], peritonitisina case of continuous ambulatory peritoneal dialysis [10], localized invasive lesion in a case of AML [12], disseminate disinfection in neutropenic patients [13]. The human infecting species include $C$. cyanescens, C. destructans, C. lichenicola and C. vaginae [14].

Previous phytochemical studies on Cylindrocarpon species have resulted in the isolation of Orsenol, Orsellinic acid, Ilicicolin (A-F), Ascochlorin, fatty acids [15], Cylindrols [16], Cylindrocyclin [17], Colletorine, Colletochlorin and Curvularine derivatives [18].

Only few metabolites such as radicicol and radicicolin [19] have been reported from Cylindrocarpon destructans $(C$. radicola). Herein we reported the isolation and structure elucidation of two new compounds (1-2) and four known compounds (3-6) from Cylindrocarpondestructan (C. radicicola). The isolated compounds were screened for cytotoxic activities.

\section{Materials and Mehods}

\subsection{General}

Optical rotations were measured with an Abbemat 300 spectrometer. NMR spectra were recorded with a Bruker Avance ( $400 \mathrm{MHz}$ for ${ }^{1} \mathrm{H}$ and $100 \mathrm{MHz}$ for ${ }^{13} \mathrm{C}$ spectrometer; Bruker Corporation, Switzerland). HRESIMS spectra were recorded using an LTQ-Orbitrap LC-MS spectrometer (Thermo Corporation, USA). UV spectra were recorded on a Blue Star A spectrophotometer. Thin layer chromatography silica gel $\mathrm{GF}_{254}$ (Qingdao Marine Chemical, Factory PR China) were used for TLC. Sephadex LH-20 (Amersham Pharmacia) and Silica gel (100-200, 200-300, and 300-400 mesh, Qingdao Marine Chemical Factory, Qingdao, PR China) were used for column chromatography. The reagents in the research process were analytical grade from Guangzhou chemical reagent factory.

\subsection{Fungal Material}

The fungal strain Cylindrocarpon destructans (or C. radicicola) (Gen accession number KC904953) was isolated from fresh roots of Meconopsisgrandis (Tibetan Blue puppy) in Tibetan Plateau near to Damxung, Tibet, China. The fungus was identified as using morphological characteristics and ITS region. A voucher specimen (DH 29) has been preserved on PDA at $4^{\circ} \mathrm{C}$ at the school of marine science, Sun YatSen University.

\subsection{Fermentation, Extraction and Fractionation}

The fungal strain was cultured for 6 days at $28{ }^{\circ} \mathrm{C}$ in Petri dishes containing Potato dextrose agar. The agar supported mycelia were then cut and transferred to $1000 \mathrm{~mL}$ Erlenmeyer flasks containing $500 \mathrm{~mL}$ potato dextrose broth (12 gm of PDB dissolved in $500 \mathrm{~mL}$ of $3 \%$ saline water) and then incubated at $28{ }^{\circ} \mathrm{C}$ for 5 days with continuous shaking on shaker at $150 \mathrm{rpm}$. Then $10 \mathrm{~mL}$ of the fungal broth were added into rice medium (110 bottles each $1000 \mathrm{~mL}$ Erlenmeyer flasks, each containing $60 \mathrm{~g}$ rice in $80 \mathrm{~mL}$ of $3 \%$ saline water) and were incubated for 30 days under static conditions and light. After incubation, the mycelia cultivated rice medium were crushed and extracted three times with methanol. The methanol extract was concentrated with rotary evaporator to get methanolic crude which was then suspended in $20 \% \mathrm{MeOH}-\mathrm{H}_{2} 0$. The suspension was then fractionated with n-hexane, chloroform, ethyl acetate to get the corresponding nhexane (15 g), Chloroform (26 g) and ethyl acetate (44 g) fractions. The chloroform extract was separated into 7 sub-fractions (J-P) by silica gel column chromatography by gradient elution of petroleum ether/ $\mathrm{CH}_{2} \mathrm{Cl}_{2}$ (from 90:10 to 00:100) and then $\mathrm{CH}_{2} \mathrm{Cl}_{2} / \mathrm{MeOH}$ (from 100:00 to 00:100). Ethyl acetate fraction was further fractionated over silica gel column chromatography with gradient elution of pet ether Ether/EtOAc (100:00 00:100) and then EtOAc/MeOH (100:00 to 00:100) to get 9 fractions (Q-Y). 


\subsection{Purification of the Compounds}

Fraction $\mathbf{M}$ was further separated over silica gel CC eluted with pet ether/ $\mathrm{CH}_{2} \mathrm{Cl}_{2}(90: 10$ to $00: 100)$ and then $\mathrm{CH}_{2} \mathrm{Cl}_{2} / \mathrm{MeOH}$ (5 and $10 \% \mathrm{MeOH}$ in $\mathrm{CH}_{2} \mathrm{Cl}_{2}$ ) to afford 5 subfractions (M-1 to M-5). Fraction M-4 was purified by sephadex LH-20 with $\mathrm{CH}_{2} \mathrm{Cl}_{2}: \mathrm{MeOH}(\mathrm{v} / \mathrm{v} ; 1: 1)$ and then by semipreparative HPLC (65\% $\mathrm{MeOH}-\mathrm{H}_{2} \mathrm{O}$ flow rate $1.5 \mathrm{ml} / \mathrm{min} ; \mathrm{C}_{18}, 10 \times 250 \mathrm{~mm}, 5 \mathrm{um}$ ) to afford two compounds (5 and 6). Fraction $\mathbf{P}$ was further separated over silica gel $\mathrm{CC}$ eluted with pet ether/ $\mathrm{CH}_{2} \mathrm{Cl}_{2}$ (90:10 to 00:100) and then $\mathrm{CH}_{2} \mathrm{Cl}_{2} / \mathrm{MeOH}$ ( 5 and $15 \% \mathrm{MeOH}$ in $\mathrm{CH}_{2} \mathrm{Cl}_{2}$ ) to afford 4 subfractions (P-1 to P-4). Fraction P-3 was purified by $\mathrm{HPLC}\left(70 \% \mathrm{MeOH}-\mathrm{H}_{2} \mathrm{O}\right.$ flow rate $\left.1.5 \mathrm{ml} / \mathrm{min} ; \mathrm{C}_{18}, 10 \times 250 \mathrm{~mm}, 5 \mathrm{um}\right)$ to afford compounds $2(13 \mathrm{mg})$.

Fraction $\mathbf{S}$ was subjected to series of silica gel chromatographic separation by gradient elution with pet ether/EtOAc and then EtOAc/MeOH and then to HPLC $\left(70 \% \mathrm{MeOH}-\mathrm{H}_{2} \mathrm{O}\right.$, flow rate $1.0 \mathrm{ml} / \mathrm{min} ; \mathrm{C} 18 ; 10 \times 250$ $\mathrm{mm}, 5 \mathrm{um}$ ) to get a pure compound 1. Fraction $\mathbf{T}$ was rechromatographed over Silica gel CC by gradient elution with EtOAc/MeOH (100:00 to 00:100) to get 7 sub-fractions (T-1 to T-7). Fraction T-6 was applied to reverse phase silica gel column $\mathrm{MeOH} / \mathrm{H}_{2} \mathrm{O}$ (70:30) and then to semipreparative HPLC with $\left(80 \% \mathrm{CH}_{3} \mathrm{CN}\right.$ $\mathrm{H}_{2} \mathrm{O}$ flow rate $1.5 \mathrm{ml} / \mathrm{min} ; \mathrm{C}_{18}, 10 \times 250 \mathrm{~mm}, 5 \mathrm{um}$ ) to yield two pure compounds (3 and 4 ).

3.4.1. 6,8-dimethoxy-3-methyl-3,4-dihydrobenzoisochromene-4,9,10-triol (1): Yellow powder; UV $(\mathrm{MeOH}) \lambda_{\max }(\log \varepsilon): 230$ (4.78), 284 (4.12), 304 (3,98), 338 (3.86) nm; HRESIMS $m / z: 307.1140[\mathrm{M}+\mathrm{H}]^{+}$ (calcd for $\mathrm{C}_{16} \mathrm{H}_{16} \mathrm{O}_{6}, 307.1136$ ). ${ }^{1} \mathrm{H}$ NMR and ${ }^{13} \mathrm{C}$ NMR data see Table 1.

3.4.2. 3,5,6-trihydroxy-4-methylbenzoisochromene-9,11-dione (2): White amorphous powder; $[\alpha]_{D}^{20}+65$, (c 0.025, MeOH); UV (MeOH) $\lambda_{\max }(\log \varepsilon): 278$ (4.12), 243 (3.41), 304 (3,98), 338 (3.86) nm; HRESIMS $m / z$ : $261.0363[\mathrm{M}+\mathrm{H}]^{+}$(calcd for $\left.\mathrm{C}_{16} \mathrm{H}_{16} \mathrm{O}_{6}, 261.0354\right) .{ }^{1} \mathrm{H}$ NMR and ${ }^{13} \mathrm{C}$ NMR data see Table 1.

\subsection{Cytotoxicity MTT Assay}

\subsection{1. $\quad$ Preparation of Cell Lines and Cell Cultures}

MCF-7, PC-3 and WI-38 cells were seeded in culture plates containing MEM, DMEM Media, glutamine $(2 \mathrm{mM})$, penicillin $(100$ Units $/ \mathrm{mL})$ and streptomycin $(100 \mu \mathrm{g} / \mathrm{mL})$ accompanied with $10 \%$ heatinactivated fetal bovine serum under humidified atmosphere at constant temperature of $37{ }^{\circ} \mathrm{C}$ in $5 \% \mathrm{CO} 2$ incubator. After achieving a monolayer with $80 \%$ confluence of both adherent cell lines, the cells were cultured in 96-well plates at a seeding density of 5000-10000/well to start cytotoxicity experiments.

\subsubsection{MTT Assays Procedure}

The method is based on the principal that was previously described by [20] with some modifications to perform cytotoxicity assay cells. The MCF-7, PC-3 and WI-38 cells were cultured for 24 thin Micro plate Elisa Reader for 96 Well Plate (ELX 800) BioTek USA. Different concentrations of test compounds $(10,1,0.1,0.01,0.001 \mu \mathrm{M})$ were inoculated in test wells while control and blank wells were also prepared using cell with media and dimethyl sulfoxide (DMSO), respectively. The plates were then incubated for $48 \mathrm{~h}$ at $37^{\circ} \mathrm{C}$. After that cells were fixed with $50 \mu \mathrm{L}$ of MTT solution at $37^{\circ} \mathrm{C}$ for $1 \mathrm{~h}$. The plates were washed 5 times with PBS (Phosphate-Buffered Saline). After that the MTT solution was removed and added $100 \mu \mathrm{L}$ of DMSO The absorbance was measured at $570 \mathrm{~nm}$ subtracting the background measurement. Results were reported as mean of three independent experiments $( \pm$ SEM) and expressed as percent inhibitions calculated by the formula. Inhibition $(\%)=[100-($ abs of test comp/abs of control $) \times 100)]$. IC50 values of selected compounds exhibiting $>50 \%$ activity at $0.5 \mathrm{mM}$ were calculated after suitable dilutions. 


\section{Results and Discussion}

The fungus Cylindrocarpon sp. DH 29 was cultured in rice solid medium for 30 days. The $\mathrm{CHCl}_{3}$ and EtOAc fraction were repeatedly fractionated and purified by using silica gel column chromatography, sephadex LH-20, reverse phase silica column and HPLC to obtain two new compound (1-2) and four known compounds (3-6) Figure 1.<smiles>COc1cc(OC)c2c(O)c3c(c(O)c2c1)[C@H](O)[C@H](OC)OC3</smiles>

1

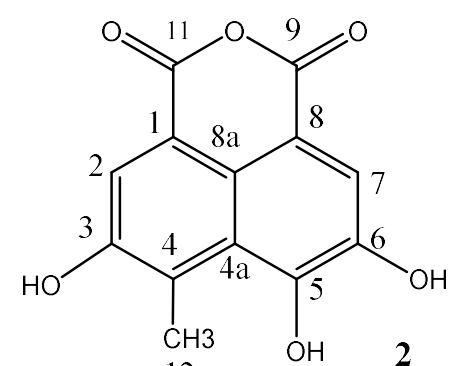

12<smiles>[R]O[R1]([H])(O)C(=O)c1c([R])c(O)c2oc3c(C)c4c(c(O)c3c2c1C)COC4</smiles><smiles>Cc1c(O)c(O)c(O)c2c1COC2</smiles>

5<smiles>Cc1c(O)c(O)c(O)c2c1C(=O)OC2</smiles>

6

Figure 1. Structures of compounds 1-6

Compound 1 was isolated as yellow amorphous powder. Its molecular formula was deduced on the basis of HRESIMS as $\mathrm{C}_{16} \mathrm{H}_{18} \mathrm{O}_{6}\left(\mathrm{~m} / z: 307.1140[\mathrm{M}+\mathrm{H}]^{+}\right.$with eight degrees of unsaturation. The ${ }^{1} \mathrm{HNMR}$ spectrum of compound 1 displayed a couple of doublets resonated at $\delta 6.10(1 \mathrm{H}, J=2.1)$ and $6.56(1 \mathrm{H}, J=$ $2.1)$ assignable to aromatic protons and a pair of doublets resonated at $\delta 4.78(1 \mathrm{H}, J=15.6)$ and $5.20(1 \mathrm{H}, J$ $=15.6)$ were attributed to two geminal oxygenated methylenic protons. The quartet of doublet at $\delta 3.71(1 \mathrm{H}$, $J=6.3,1.7)$ and a doublet resonated at $\delta 3.83(1 \mathrm{H}, J=1.7)$ were characteristics of two vicinal methine protons. COSY correlation (Figure S6) between the two H-1 proton established their geminal relationship while the correlation between H-3 and H-4 suggested their vicinal relationship. The two methoxy groups exhibited signals at $\mathrm{H} \delta 3.43(3 \mathrm{H}, \mathrm{s})$ and $4.09(3 \mathrm{H}, \mathrm{s})$ and the doublet at $\delta 1.19(3 \mathrm{H}, J=6.3)$ was due to methyl protons. The ${ }^{13} \mathrm{CNMR}$ spectrum along with DEPT experiment showed the presence of four tertiary carbons that include two aromatic and two oxygenated methine carbons, one oxygenated methylene carbon, three primary carbons including two methoxy and one methyl carbons and eight quaternary carbons. The HMBC (Figure S8) correlations from $\mathrm{H}-5$ to $\mathrm{C}-6, \mathrm{C}-8 \mathrm{a}, \mathrm{C}-10 \mathrm{a}$ and from $\mathrm{H}-7$ to $\mathrm{C}-8$ and $\mathrm{C}-8 \mathrm{a}$ were in consistent with the position of these protons. Finally the structure of compound $\mathbf{1}$ was assigned as 6,8-dimethoxy-3-methyl-3,4dihydrobenzoisochromene-4,9,10-triol on the basis of the spectral data that share common structural unit 
with the compounds available in literature $[21,22)$. The structure of compound 1 was further confirmed by 2D experiments and mass spectra (Figure S6- S8).

Table 1. ${ }^{1} \mathrm{H}(400 \mathrm{MHz})$ and ${ }^{13} \mathrm{C}(100 \mathrm{MHz})$ NMR data for Compound $\mathbf{1}$ and Compound $\mathbf{2}$ (MeOD)

\begin{tabular}{|c|c|c|c|c|}
\hline \multirow[t]{2}{*}{ Position } & 1 & \multicolumn{3}{|c|}{2} \\
\hline & $\delta \mathbf{H}(\boldsymbol{J}$ in $\mathbf{H z})$ & $\delta \mathbf{C}$ & $\delta \mathbf{H}(\boldsymbol{J}$ in $\mathbf{H z})$ & $\delta \mathbf{C}$ \\
\hline 1 & $\begin{array}{c}4.78(1 \mathrm{H}, \mathrm{d}, J=15.6), 5.20(1 \mathrm{H}, \mathrm{d}, \\
J=15.6)\end{array}$ & 66.52 & & 97.0 \\
\hline 2 & & & $6.81(1 \mathrm{H}, \mathrm{s})$ & 117.3 \\
\hline 3 & $3.71(1 \mathrm{H}, \mathrm{qd}, J=6.3,1.7)$ & 73.97 & & 166.7 \\
\hline 4 & $3.83(1 \mathrm{H}, \mathrm{d}, J=1.7)$ & 66.02 & & 112.4 \\
\hline $4 a$ & & 134.48 & & 151.7 \\
\hline 5 & $6.56(1 \mathrm{H}, \mathrm{d}, J=2.1)$ & 99.13 & & 165.4 \\
\hline 6 & & 149.2 & & 164.7 \\
\hline 7 & $6.10(1 \mathrm{H}, \mathrm{d}, J=2.1)$ & 97.62 & $6.42(1 \mathrm{H}, \mathrm{s})$ & 99.5 \\
\hline 8 & & 136.44 & & 91.7 \\
\hline $8 \mathrm{a}$ & & 109.95 & & 136.9 \\
\hline 9 & & 157.14 & & 167.9 \\
\hline $9 a$ & & 113.54 & & \\
\hline 10 & & 157.10 & & \\
\hline $10 \mathrm{a}$ & & 124.88 & & \\
\hline 11 & $1.19(3 \mathrm{H}, \mathrm{d}, J=6.3)$ & 15.02 & & 167.6 \\
\hline 12 & & & $2.87(3 \mathrm{H}, \mathrm{s})$ & 25.05 \\
\hline $6-\mathrm{OCH}_{3}$ & $4.09(3 \mathrm{H}, \mathrm{s})$ & 55.46 & & \\
\hline $8-\mathrm{OCH}_{3}$ & $3.43(3 \mathrm{H}, \mathrm{s})$ & 53.98 & & \\
\hline
\end{tabular}

Compound 2 was isolated as white amorphous powder. The HREIMS spectra gave $[\mathrm{M}+\mathrm{H}]+$ peak at $\mathrm{m} / \mathrm{z} 261.0363$ consistent with the molecular formula of C13H8O6 corresponding to nine degrees of unsaturation. The ${ }^{1} \mathrm{HNMR}$ spectrum of compound 2 displayed a couple of singlets resonated at 6.81 and 6.42 assignable to aromatic protons. A singlet resonated at 2.87 was characteristics of methyl protons. ${ }^{13} \mathrm{C}$ NMR spectrum exhibited signals for 13 carbon that were assigned by DEPT as two aromatic methine carbons, one methyl carbon and ten quaternary carbons that include two carbonyl carbon and eight fully substituted aromatic carbons. The aromatic protons were found to show a long range HMBC correlations with the carbonyl carbons resonated at 167.9 and 167.6 indicated the connectivity of these protons at C-2 and C-7 respectively. On the basis of these analysis the structure of compound 2 was assigned as 3,5,6-trihydroxy-4methylbenzoisochromene-9,11-dione that has close resemblance with the available literature (Lin et al. 2012). The known compounds 3-6 were identified by comparison of their spectral data with the literature available and include Preussiafuran A (3), Preussiafuran B (4) [24], 4,5,6-trihydroxy-7-methyl-1,3dihydroisobenzofuran (5), 4,5,6-trihydroxy-7-methylphthalide (6) [25].

The compounds 1-6 were evaluated for their in vitro cytotoxicity (Table 2). All the compounds were analyzed against two different cancer cell lines cell lines MCF-7 and PC-3 was determined by MTT assay. Tamoxifen was used as standard drug. The compounds 1, 2, 3 and 4 inhibit MCF-7 with $\mathrm{IC}_{50}$ values of $05.37 \pm 1.03,09.02 \pm 1.20,08.04 \pm 2.10,10.04 \pm 0.20$ and Cell viability (\%) $03.02 \pm 2.11,6.07 \pm 0.30$, $04.14 \pm 0.81,05.21 \pm 0.01(\mu \mathrm{M})$. The PC-3 with $\mathrm{IC}_{50}$ values of $04.12 \pm 0.38,12.07 \pm 0.11,09.41 \pm 1.81$ and $08.13 \pm 2.31(\mu \mathrm{M})$ and Cell viability $(\%) 2.04 \pm 0.09,07.14 \pm 1.2,05.41 \pm 07$ and $04.71 \pm 0.62$ respectively. The compounds 5-6 showed minimum inhibitory effect of cancerous cell lines growth. 
Table 2. Cytotoxicity of compounds 1-6, $\mathrm{IC}_{50}$ values $(\mu \mathrm{M})$ and cell survival (values \pm standard Deviation) ${ }^{*}$

\begin{tabular}{|c|c|c|c|c|}
\hline \multirow{3}{*}{$\overline{\text { Compounds }}$} & \multicolumn{4}{|c|}{$\mathrm{IC50}^{2} \mathrm{SEM}^{\mathrm{a}}$} \\
\hline & \multicolumn{2}{|c|}{ MCF-7 } & \multicolumn{2}{|r|}{ PC-3 } \\
\hline & $I_{50}(\mu M)$ & Cell survival (\%) & $\mathrm{IC}_{50}(\boldsymbol{\mu M})$ & Cell survival (\%) \\
\hline 1 & $5.37 \pm 1.03$ & $3.02 \pm 2.11$ & $4.12 \pm 0.38$ & $2.04 \pm 0.09$ \\
\hline 2 & $9.02 \pm 1.20$ & $6.07 \pm 0.30$ & $12.07 \pm 0.11$ & $7.14 \pm 1.2$ \\
\hline 3 & $8.04 \pm 2.10$ & $4.14 \pm 0.81$ & $9.41 \pm 1.81$ & $5.41 \pm 07$ \\
\hline 4 & $10.04 \pm 0.20$ & $5.21 \pm 0.01$ & $8.13 \pm 2.31$ & $4.71 \pm 0.62$ \\
\hline 5 & $24.18 \pm 1.08$ & 9.020 .05 & $28.07 \pm 0.02$ & $7.02 \pm 0.20$ \\
\hline 6 & $18.04 \pm 0.10$ & $10.27 \pm 2.47$ & $21.04 \pm 0.20$ & $8.04 \pm 0.22$ \\
\hline Tamoxifen $^{b}$ & \multicolumn{2}{|c|}{$0.00053 \pm 0.0004$} & \multicolumn{2}{|c|}{$0.0036 \pm 0.0007$} \\
\hline
\end{tabular}

\title{
Acknowledgments
}

Thanks to Guangdong Provincial ministry of Education for financial support during post doctorate fellowship at Sun Yat-Sen University, China. Instrumental Analysis and Research Center of Sun Yat-Sen University is specially acknowledged for their assistance in acquisition of mass spectra regarding this work.

\section{Supplementary material}

Supporting Information accompanies this paper on http://www.acgpubs.org/journal/recordsof-natural-products

\section{Conflict of interest}

The authors declare no conflict of interest.

\author{
ORCID \\ Dilfaraz Khan:0000-0003-0971-0124 \\ Shah Iram Niaz:0000-0001-7083-9790 \\ Kamran Tahir: 0000-0001-9505-1414 \\ Hidayat Ullah Khan:0000-0002-3099-6983 \\ Muhammad Haroon:0000-0003-0763-448X \\ Shahid Ullah Khan: 0000-0002-3082-6079 \\ Syed Badshah:0000-0001-8888-7387 \\ Shafiullah Khan:0000-0003-4306-4752 \\ Muafia Jabeen: $0000-0002-2610-0435$ \\ Lui Lan: 0000-0003-2765-4015
}

\section{References}

[1] D. Brayford (1993) Cylindrocarpon. In: Methods for research on soil-borne phytopathogenic fungi. (Singleton LL, Mihail JD, Rush M, eds). APS Press, Saint. Paul, U.S.A.: 103-106.

[2] C. Booth (1966). The Genus Cylindrocarpon. Mycological Papers No. 104, Commonwealth Mycological Institute, England, pp. 35-37.

[3] K. A. Seifert, C. R. McMullen, D. Yee, R. D. Reeleder and K. F. Dobinson (2003). Molecular differentiation and detection of ginseng-adapted isolates of the root rot fungus Cylindrocarpon destructans, Phytopathology, 93, 1533-1542.

[4] D. R. Maluta and P. Larignon (1991). Pied-noir: Mieuxvautprévenir, Viticulture 11, 71-72. 
[5] S. Grasso and S. L. di Magnano (1975). Infections of Cylindrocarpon obtusisporum on grape vines in Sicily, Vitis 14, 36-39.

[6] H. J. Scheck, S. J. Vasquez, D. Fogle and W. D. Gubler (1998). Grape growers report losses to black-foot and grapevine decline, Calif. Agric. 52, 19-23.

[7] J. Kaliamurthy, C. Jesudasan, D. A. Prasanth and P. A. Thomas (2006). Keratitis due to Cylindrocarpon lichenicola, J. Postgrad. Med. 52, 155-157.

[8] T. Gaujoux, E. Borsali, J. C. Gavrilov, O. Touzeau, P. Goldschmidt and M. O. Despiau (2012). Fungal keratitis caused by Cylindrocarpon lichenicola, J. Fr. Ophtalmo. 35 (5), 356.

[9] D. E. Zoutman and L. Singler (1991). Mycetoma of the foot caused by Cylindrocarpon destructans, J. Clin. Microbiol. 29 (9), 1855-1859.

[10] R. Sharma, C. K. Farmer, W. R. Gransden and C. S. Ogg (1988). Peritonitisin continuous ambulatory peritoneal dialysis due to Cylindrocarpon lichenicola infection, Nephrol. Dial. Transplant. 13, 2662-2664.

[11] B. Lancy, C. Blanc and J. Lapalu (1985). Cylindrocarpon: Anewathlete's foot agent, Bull. Trimest. Soc. Mycol. Fr. 14, 73-76.

[12] P. C. Iwen, S. R. Tarantolo, D. A. Sutton, M. G. Rinaldi and S. H. Hinrichs (2000). Cutaneous infections caused by Cylindrocarpon lichenicolain a patient with acute leukemia, J. Clin. Microbiol. 38 (9), 3375-3378.

[13] E. A. James, D. K Orchar, P. H. Mcwhinney, D. W. Warnock, E. M. Johnson and A.B. Mehta (1997). Disseminated infection due to Cylindrocarpon lichenicola in a patient with acute myeloid leukemia, J. Infect. 34, 65-67.

[14] C. Booth, Y. M. Clayto and M. Usherwood (1985). Cylindrocarpon species associated with mycotic keratitis, Proceed. Ind. Acad. Sci. 2 (3), 433-436

[15] K. Mio, F. Takashi, U. Ryuji, N. Kenichi, M. Rokuro and T Hiroshi (2013). A new ascochlorin derivative from Cylindrocarpon sp. FKI-4602, J. Antibiot. 66, 23-29.

[16] B. S. Sheo, G. B. Richard, F. B. Gerald, C. Carmen, B. G. Jackson, A. G. Michael, H. Karst, G. J. Rosalind, M. L. Jerrold, B. L. Russell, C. S. Keith and L. Z. Deborah (1996). Chemistry and biology of cylindrols: Novel inhibitors of ras farnesyl-protein transferase from Cylindrocarpon lucidum, J. Org. Chem. 61, 7727-37.

[17] W. Daniela, E. Gilda, S. Olov and A. Timm (2006). Cylindrocyclin A, a new cytotoxic cyclopeptide from Cylindrocarpon sp., J. Antibiot. 59 (8), 495-499.

[18] G. R. Margarita, T. Cristina, R. Jaime, L. Mauricio and S. H. Guillermo (2005). Bioactive metabolites from the fungus Nectriagalligena, the main apple canker agent in Chile, J. Agric. Food Chem. 53, 7701-7708.

[19] G. Evans and N. H. White. (1966). Radicicolin and radicicol, two new antibiotics produced by Cylindrocarpon radicicola, Trans. Br. Mycol. Soc. 49 (4), 563-576

[20] T. Mosmann (1983). Rapid colorimetric assay for cellular growth and survival: Application to proliferation and cytotoxicity assays, J. Immunol. Methods. 16, 55-63.

[21] O. Jaturapat, M. Isaka, N. L. Hywel-Jones, Y. Lertwerawat, S. Kamchonwongpaisan, K. Klrtikara, M. Tanticharoen and Y. Thebtaranonth (2001). Bioxanthracenes from the insect pathogenic fungus Cordycepspseudo militaris BCC1 620, I, J. Antibiot. 54 (1), 29-35

[22] M. Isaka, P. Kongsaeree and Y. Thebtaranonth (2001). Bioxanthracenes from the insect pathogen fungus Cordycepspseudo militaris BCC1 620, II, J. Antibiot. 54 (1), 36-43.

[23] H. Lin, Y. W. Zhang, Y. Hua, Y. L. Bao, Y. Wu, S. L. Gun, C. L. Yu, Y. X. Huang, E. B. Wang, H. Y. Jiang and Y. X. Li (2014). Three new compounds from the stem bark of Juglans mandshurica, J. Asian Nat. Prod. Res. 16 (8), 819-824.

[24] F. M. Talontsi, M. Lamshöft, C. Douanla-Meli, S. F. Kouam and M. Spiteller (2014). Antiplasmodial and cytotoxic dibenzofurans from Preussiasp. Harbouredin enantiachlorantha oliv, Fitoterapia 93, 233-238.

[25] A. Z. Huang, Y. Zhu, X. L. Guan, K. Tian, J. M. Guo, H. B. Wang and G. M. Fu (2012). A novel antioxidant isobenzofuranone derivativefrom fungus Cephalosporium sp. AL031, Molecules 17, 4219-4224.

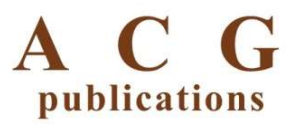

(C) 2018 ACG Publications 